\title{
PENDAMPINGAN DAN TUTORIAL ASI EKSKLUSIF SEBAGAI UPAYA MEMBENTUK SISTEM IMUNITAS SERTA KECERDASAN PADA ANAK
}

\author{
ACCOMPANIMENT AND TUTORIAL ASI EXCLUSIVE \\ AS EFFORTS FORMING THE IMMUNITY SYSTEM AS WELL AS \\ INTELLIGENCE IN CHILDREN
}

\author{
Dewi Anggreini \\ Program Studi Pendidikan Matematika STKIP PGRI Tulungagung \\ Jalan Mayor Sujadi Timur No.7 Tulungagung \\ E-mail: anggreini_004@yahoo.com
}

\begin{abstract}
ABSTRAK
ASI adalah makanan terbaik baik bagi bayi yang mengandung gizi paling lengkap untuk pencernaan, perkembangan otak dan pertumbuhan bayi. Perlunya Pendampingan dan Tutorial ASI eksklusif di Kelurahan Jepun disebabkan beberapa hal yaitu berdasarkan data dari profil kesehatan Kabupaten Tulungagung tahun 2016 diketahui bahwa jumlah ASI eksklusif di Kabupaten Tulungagung adalah sebesar 34,53\%. Kelurahan Jepun masih memiliki cakupan ASI eksklusif cukup rendah, yaitu dari usia bayi 0-6 bulan hanya 11 anak dari total 40 bayi yang mendapat ASI eksklusif. Rendahnya pengetahuan masyarakat tentang pentingnya asi ekslusif bagi bayi usia 0-6 bulan, para ibu lebih memilih memberikan susu formula serta MP-ASI, faktor budaya, tuntutan pekerjaan, serta banyaknya iklan susu formula di media masa dan elektronik. Tujuan dari kegiatan ini adalah 1) Meningkatkan pemahaman dan pengetahuan ibu-ibu menyusui tentang manfaat ASI eksklusif bagi bayi usia 0-6 bulan, 2) Meningkatkan pengetahuan tentang manfaat pemberian asi sampai dua tahun penuh bagi kecerdasan dan sistem imunitas pada anak. Metode yang digunakan dalam kegiatan ini adalah ceramah dan demontrasi posisi menyusui bayi dengan benar. Dari hasil pendampingan di Posyandu V Kelurahan Jepun diketahui bahwa ibunda yang memahami pentingnya asi ekkslusif dan mengetahui pengetahuan tentang mitos-mitos menyusui dini mengalami peningkatan sebesar 90\% dari total ibunda anak. Hasil dari kegiatan adalah meningkatnya pengetahuan ibunda akan ASI eksklusif bagi bayi 0 - 6 bulan dan menyempurnakan pemberian ASI hingga 2 tahun, terciptanya kader ASI (KASI) di Kelurahan Jepun dengan menggandeng dokter dan bidan dari Puskesmas Kecamatan Tulungagung, Terciptanya modul pentingnya ASI eksklusif sebagai pembentuk sistem imunitas dan kecerdasan bagi bayi sebagai pegangan ibunda bayi.
\end{abstract}

Kata Kunci: ASI Eksklusif, Kecerdasan, Imunitas, Tutorial

\begin{abstract}
Breast milk is the best food for babies that contain the most complete nutrition for digestion, brain development and infant growth. The need for exclusive ASI Assistance and tutorial in Jepun Village is due to several things, based on data from the health profile of Tulungagung Regency in 2016, it is known that the number of exclusive breastfeeding in Tulungagung Regency is 34.53\%. The urban village of Jepun still has very low coverage of exclusive breastfeeding, from 0-6 months old infants only 11 children out of 40 exclusively breastfed babies. The low level of public knowledge about the importance of exclusive breastfeeding for infants aged 0-6 months, mothers prefers to provide formula milk and breast milk, cultural factors, job demands, and the number of formula milk advertising in mass media and electronics. The purpose of this activity is 1) Increasing the level of understanding and knowledge of breastfeeding mothers about the benefits of exclusive breastfeeding for infants aged 0-6 months, 2) Increase knowledge about the benefits of giving up to two years full for intelligence and immune systems in children. The
\end{abstract}


method used in this activity is lecturing and demonstrating the position of breastfeeding the baby properly. From the results of assistance at Posyandu V Kelurahan Jepun it is known that moms who understand the importance of exclusive ation and know the knowledge of early breastfeeding myths have increased by 90\% from total child's mother. The result of the activity is the increasing of mother's knowledge of exclusive breastfeeding for baby 0-6 months and complete breastfeeding for 2 years, the creation Cadre of ASI (KASI) in Jepun Village by holding doctor and midwife from Puskesmas Kecamatan Tulungagung, Making the module of the importance of exclusive breastfeeding as the founder of the immune system and intelligence for infants as the mother's guidance.

Keyword: Exclusive Breast Milk,Intelligence, Immunity, Tutorial

Submitted : 30 Januari $2018 \quad$ Revision : 1 Agustus 2018 Accepted : 9 Agustus 2018

\section{PENDAHULUAN}

Indikator kesehatan bayi dapat diukur dengan Angka Kematian Bayi (AKB), Salah satu penyebab tingginya AKB adalah pemberian susu formula dan MP-ASI sebelum bayi berusia 6 bulan. Hal itu terjadi karena sistem immune dan sistem pencernaan bayi belum tumbuh secara sempurna. Penyebab tingginya AKB dapat dicegah dengan pemberian ASI secaraeksklusif. ASI eksklusif adalah ASI yang diberikan kepada bayi sampai usia 6 bulan tanpa diberikan makanan dan minuman, kecuali obat dan vitamin (Dinas Kesehatan, 2016). ASI adalah hadiah yang sangat berharga yang dapat diberikan kepada bayi, dalam keadaan miskin dan darurat mungkin merupakan satu-satunya, dalam keadaan sakit mungkin merupakan hadiah yang menyelamatkan jiwanya (Roesli, 2008).

Sejumlah riset menunjukkan bayi yang diberi asi lebih jarang terserang Gastroenteritis, infeksi pernapasan, infeksi telinga, infeksi saluran kemih, alergi, asma, dan eksim. (Heather \& Welford, 2001).Pemberian ASI perlu diberikan secara eksklusif sampai usia 6 bulan dan tetap mempertahankan pemberian ASI dilanjutkan bersama makanan pendamping sampai usia 2 tahun sesuai dengan kebijakan nasional yang telah ditetapkan dalam SK Menteri Kesehatan N0 450/Menkes/SK/IV/2004.
Beberapa penelitian membuktikan bahwa menyusui secara eksklusif dapat mencegah timbulnya berbagai penyakit. Penelitian di Amerika Latin melaporkan bahwa 55\% kematian bayi dikarenakan diare dan infeksi saluran pernapasan atas dapat dicegah dengan pemberian ASI eksklusif diantara bayi umur 0-3 bulan. Mustofa \& Prabandari (2010), menemukan bahwa ASI adalah makanan terbaik bagi bayi dan asi ekslusif harus diberikan sampai bayi berusia 6 bulan agar bayi menjadi sehat, cerdas dan tumbuh dengan kekebalan penuh terhadap virus dan penyakit. Terdapat dua problem ketika ibu menyusui yaitu faktor internal dan eksternal.

Menurut Werdika, Mardji \& Devi (2014) ada pengaruh penyuluhan ASI Eksklusif terhadap pengetahuan ibu menyusui dan sikap ibu menyusui. Hanafi (2012) juga mengatakan ASI lebih berpotensi meningkatkan kecerdasan anak dibandingkan susu formula karena kandungan Taurin, DHA, dan AA yang berperan dalam pembentukan sel otak. Anjuran pemberian asi selama dua tahun pertama berpengaruh terhadap perkembangan otak pada dua tahun pertama.

Manfaat ASI bagi sistem imunitas menurut Marimbi \& Hanum (2010) yaitu : 1) Menghambat pertumbuhan bakteri yang pathologis, 2) Merangsang pertumbuhan 
mikroorganisme yang dapat menghasilkan beberapa asam organic dan mensintesa beberapa jenis viamin dalam usus, 3) ASI mengandung berbagai antibody yang dapat melindungi bayi dari berbagai penyakit infeksi, 4) Melindungi terhadap asma dan mengurangi risiko alergi pada bayi.

Fungsi spesifik zat gizi dalam ASI yang berperan dalam pertumbuhan otak: 1) Lemak jenuh ikatan Panjang (DHA dan AA) untuk pertumbuhan otak dan retina 2) Kolesterol untuk mielinisasi jaringan syarat 3) Taurin Neurotransmiter inhibitor dan stabilitator 4) Laltosa untuk pertumbuhan otak. 5) Kolin untuk meningkatkan memory dan masih banyak lagi (Roesli, 2008).

Melihat besarnya manfaat ASI tersebut, progam peningkatan penggunaan ASI merupakan salah satu progam utama bidang kesehatan ibu dan anak. Progam ini berkaitan dengan kesepakatan global antara lain Declarasi Innocenti (Italia) tahun 1990 tentang perlindungan, promosi dan dukungan terhadap pengguna ASI. Deklarasi tersebut menghimbau agar semua negara di dunia mengambil kebijakan serta menentukan target terhadap ASI eksklusif (Roesli, 2003).

Tabel berikut menunjukkan komposisi kolostrum dan ASI matur :

Tabel 1. Komposisi Kolostrum dan ASI Matur

\begin{tabular}{lcc}
\hline $\begin{array}{l}\text { Kandungan (per } \\
\mathbf{1 0 0} \text { } \mathbf{L} \text { ) }\end{array}$ & Kolostrum & ASI Matur \\
\hline Energi $(\mathrm{kkal})$ & 58 & 70 \\
\hline Laktosa $(\mathrm{gr})$ & 5,3 & 7,3 \\
\hline Protein Total $(\mathrm{gr})$ & 2,3 & 0,9 \\
\hline IgA $(\mathrm{mg})$ & 364 & 142 \\
\hline Lemak $(\mathrm{gr})$ & 2,9 & 4,2 \\
\hline Vitamin A $(\mu \mathrm{g})$ & 89 & 67 \\
\hline Vitamin $\mathrm{D}(\mu \mathrm{g})$ & - & 0,05 \\
\hline Vitamin E $(\mu \mathrm{g})$ & 1280 & 315 \\
\hline Vitamin K $(\mu \mathrm{g})$ & 0,23 & 0,21 \\
\hline Thiamin $(\mu \mathrm{g})$ & 15 & 21 \\
\hline Riboflavin $(\mu \mathrm{g})$ & 25 & 35 \\
\hline Niacin $(\mu \mathrm{g})$ & 75 & 150 \\
\hline Asam Folat $(\mu \mathrm{g})$ & - & 8,5 \\
\hline Vitamin B6 $(\mu \mathrm{g})$ & 12 & 93 \\
\hline
\end{tabular}

\begin{tabular}{lcc} 
Vitamin B12 $(\mathrm{ng})$ & 200 & 26 \\
\hline Vitamin C $(\mathrm{mg})$ & 4,4 & 4,0 \\
\hline Kalsium $(\mathrm{mg})$ & 23 & 28 \\
\hline Natrium $(\mathrm{mg})$ & 48 & 18 \\
\hline Kalium $(\mathrm{mg})$ & 74 & 58 \\
\hline Fosfor $(\mathrm{mg})$ & 14 & 15 \\
\hline Zat Besi $(\mu \mathrm{g})$ & 45 & 40 \\
\hline Selenium $(\mu \mathrm{g})$ & - & 2,0 \\
\hline Magnesium $(\mu \mathrm{g})$ & - & 0,6 \\
\hline Zinc $(\mu \mathrm{g})$ & 540 & 120
\end{tabular}

Berdasarkan data dari Dinas Kesehatan tentang profil kesehatan Kabupaten Tulungagung tahun 2016 diketahui bahwa cakupan ASI eksklusif masih lebih rendah dari cakupan Provinsi maupun nasional, yaitu sebesar 34,53\% pada tahun 2016 (Dinas Kesehatan, 2016). Dari beberapa kelurahan di Kecamatan Tulungagung, Kelurahan Jepun merupakan daerah dengan cakupan ASI eksklusif terendah. Hal tersebut dapat ditunjukan dengan data bahwa dari 377 bayi usia 0-6 bulan hanya 12 bayi $(3,0 \%)$ yang mendapat ASI eksklusif.

Rendahnya perkembangan pemberian Air Susu Ibu (ASI) eksklusif di Indonesia disebabkan oleh penyebarluasan informasi diantara petugas kesehatan dan masyarakat yang tidak optimal, yaitu hanya sekitar $60 \%$ masyarakat tahu informasi tentang ASI dan baru ada sekitar $40 \%$ tenaga kesehatan terlatih yang bisa memberikan konseling menyusui.

Berdasarkan data dari Puskesmas Kelurahan Jepun diketahui bahwa jumlah bayi pada bulan Januari sampai Desember 2016 adalah sebanyak 69 bayi, kemudian dari jumlah tersebut yang mendapatkan ASI eksklusif sampai dengan usia 6 bulan adalah sebanyak 25 bayi atau $36 \%$. Berdasarkan hasil survey langsung di Kelurahan Jepun didapatkan hasil bahwa mayoritas ibu yang menyusui masih menganut budaya yang menyatakan bahwa ketika bayi menangis menandakan ia lapar dan harus segera diberikan MP-ASI atau susu formula. Berdasarkan hal itu maka diperlukan pembentukan kader ASI eksklusif untuk meluruskan budaya tersebut. Tujuan dari kegiatan ini adalah: 
1) Meningkatkan tingkat pemahaman dan pengetahuan ibu-ibu menyusui tentang manfaat ASI eksklusif bagi bayi usia 0-6 bulan, 2) Meningkatkan pengetahuan tentang manfaat pemberian ASI sampai dua tahun penuh bagi kecerdasan dan sistem imunitas pada anak.

\section{METODE PELAKSANAAN}

Peserta posyandu di Pos 5 terdiri dari 40 Ibunda anak. Berdasarkan beberapa faktor dilapangan dapat dijelaskan lebih terinci dengan data sebagai berikut:

a. Latar belakang pendidikan ibunda anak dapat dilihat dalam tabel berikut :

Tabel 1. Data Tentang Latar Belakang Pendidikan Ibunda Anak

\begin{tabular}{c|c|c|c}
\hline No & Lulusan & Jumlah & $\%$ \\
\hline 1 & SD & 2 & $5 \%$ \\
\hline 2 & SMP & 8 & $20 \%$ \\
\hline 3 & SMA & 25 & $62.5 \%$ \\
\hline 4 & S1 & 5 & $12.5 \%$ \\
\hline
\end{tabular}

b. Usia Ibunda Anak dapat dilihat dalam tabel berikut :

Tabel 2. Data tentang Usia Ibunda Anak

\begin{tabular}{c|c|c|c}
\hline No & Usia Ibunda & Jumlah & $\%$ \\
\hline 1 & $16-20 \mathrm{TH}$ & 21 & $52.5 \%$ \\
\hline 2 & $21-25 \mathrm{TH}$ & 13 & $32.5 \%$ \\
\hline 3 & $26-35 \mathrm{TH}$ & 6 & $15.0 \%$ \\
\hline
\end{tabular}

c. Data Ibu yang memberikan asi eksklusif (0-6 bulan) di Pos 5 Kelurahan Jepun

Tabel 3. Data Pemberian ASI Eksklusif di Pos 5

\begin{tabular}{c|c|c|c}
\hline No & $\begin{array}{c}\text { Susu } \\
\text { Formula }\end{array}$ & $\begin{array}{c}\text { ASI } \\
\text { Eksklusif }\end{array}$ & Total \\
\hline 1 & 29 & 11 & 40 \\
\hline 2 & $72.0 \%$ & $28.0 \%$ & $100.0 \%$ \\
\hline
\end{tabular}

Prosedur kerja untuk mencapai keberhasilan pelaksanaan pelatihan adalah dengan menawarkan solusi permasalahan melalui serangkaian kegiatan dengan melibatkan partisipatori aktif dari Puskesmas Tulungagung sebagai berikut:

1. Pembuatan modul tutorial untuk meningkatkan kesediaan masyarakat dalam memberikan ASI eksklusif pada bayi usia 0-6 bulan di Kelurahan Jepun sehingga terbentuk kemandirian, kepatuhan, dan kesadaran diri masyarakat dalam memberikan ASI eksklusif bagi bayinya.

2. Menjalin kerjasama dengan bidan di wilayah kerja Puskesmas Tulungagung untuk mengadakan penyuluhan kepada masyarakat di Kelurahan Jepun

3. Pembentukan kader ASI eksklusif wilayah kerja Kelurahan Jepun untuk membantu melancarkan program pelatihan dan penyuluhan kepada masyarakat di Kelurahan Jepun

4. Pelatihan dan penyuluhan kepada pasangan usia produktif, remaja dan keluarga tentang pentingnya ASI eksklusif serta dampak dari pemberian susu formula dan makanan pendamping ASI, dengan melibatkan kader ASI eksklusif yang sudah dibentuk.

Dalam realisasinya, langkah-langkah pelatihan tersebut dikemukakan berikut ini.

1. Tim pelaksana berkoordinasi dengan Puskesmas Tulungagung Kota dan Bapak Lurah Jepun untuk mendiskusikan awal rencana kegiatan yang dirancang, mencakup materi, model pelatihan, waktu dan tempat pelaksanaan, peserta dan sebagainya. Dari diskusi ini diputuskan hal-hal berikut.

a. Peserta adalah seluruh warga masyarakat Jepun khususnya ibu yang memiliki anak (bayi) di daerah Kelurahan Jepun Kabupaten Tulungagung. Peserta yang diikutkan dalam pelatihan ini diutamakan bagi ibu-ibu yang masih memiliki bayi diusia 6 bulan kebawah, sehingga tujuan pelatihan bisa tercapai secaramaksimal.

b. Tempat kegiatan di Rumah Ketua RT 05 Kelurahan Jepun Kabupaten Tulungagung

c. Waktu penyelenggaraan yaitu dua 
hari, satu hari untuk proses perizinan dan koordinasi dengan Puskesmas, Kelurahan dan Ketua RT 05. Dan satu hari untuk Pelaksanaan Program Pendampingan.

d. Tim pelaksana menyediakan perlengkapan sajian berupa Modul ASI Eksklusif, perangkat Alat Menyusui dan Media Presentasi. Konsumsi disiapkan oleh tim pelaksana dengan dana berasal dari panitia pelaksana.

2. Proses interaksi penyaji-peserta dilakukan dengan pola penyajian satu unsur setiap kali pendampingan. Dimulai dari apa itu ASI Eksklusif, Mitos-mitos IMD, Manfaat ASI dan gizi yang terkandung dalam ASI. Kegiatan terlaksana dalam bentuk berikutini.

a. Penyaji menyajikan materi sajian, berikut contoh-contoh dan ilustrasi, materi menyusui yang disajikan melalui paper oleh penyaji.

b. Sesi berikutnya, para peserta diberikan kesempatan untuk bertanya menyampaikan hal-hal yang belum dipahami dan bertukar pengalaman terkait kendala-kendala yang pernah dialami dalam menyusui.

c. Selesai sesi Tanya jawab, peserta, penyaji dan panitia pelaksana istirahat untuk menikmati sajian snack selama 15 menit.

d. Tahap selanjutnya para peserta ditugaskan untuk mencoba mengisiquestioner seputar ASI Ekslusif baik manfaat dan mitosmitos seputar ASI Eksklusif. selama mengisi questioner tersebut, penyaji selalu monitoring peserta.

e. Setelah pelaksanaan pendampingan selesai hasil jawaban questioner dibahas dan diambil kesimpulan sebagai bahan refleksi dan evaluasi. Evaluasi dan bahan refleksi ini diharapkan menjadi umpan balik bagi peserta pelatihan .

\section{HASIL DAN PEMBAHASAN}

a. Pengetahuan ibunda anak tentang manfaat ASI bagi kesehatan dan imunitas bayi masih sangat rendah, dimana hampir rata-rata setiap bayi hanya diberikan ASI Ekslusif selama 13 bulan setelah itu langsung diberikan makanan pendamping ASI. Disamping kesadaran akan pentingnya ASI, ratarata ibunda yang melakukan imunisasi campak, polio dan TBG masih sangat sedikit. Pentingnya imunisasi bagi si bayi masih belum semua ibunda melaksanakannya, sesuai dengan ketentuan dan anjuran waktu yang ditetapkan oleh Dinas Kesehatan. Dari hasil jawaban angket dan wawancara yang dilakukan, diperoleh data sebagai berikut :

Tabel.4 Distribusi jawaban dari wawancara mengenai manfaat ASI ekslusif bagi bayi

\begin{tabular}{|c|c|c|c|}
\hline No & Mengetahui & $\begin{array}{c}\text { Belum } \\
\text { Mengetahui }\end{array}$ & Total \\
\hline 1 & 25 & 15 & 40 \\
\hline 2 & $62.0 \%$ & $38.0 \%$ & $100.0 \%$ \\
\hline
\end{tabular}
menunjukan bahwa ibunda bayi masih ada yang belum faham dan mengerti arti tentang pemberian ASI Ekslusif bagi bayi, adapun ibunda yang sudah mengerti akan pentingnya asi sebanyak 25 orang atau $62 \%$, sedangkan yang belum mengetahui tentang manfaat dan pentingnya ASI Ekslusif sebanyak 15 orang atau sebesar $38 \%$.

b. Pemahaman ibunda bayi dalam memahami mitos-mitos Inisiasi Menyusui Dini (IMD) dan seputar tentang Balita. Sebelum dilaksanakan kegiatan pendampingan dan penyuluhan, pemahaman akan informasi berkenaan dengan MitosMitos yang ada di masyarakat sudah sangat melekat di pemikiran ibunda bayi, adapun datanya sbb:

Sebelum Pelaksanaan Kegiatan 
Tabel 5. Pemahaman akan informasi Mitos-Mitos IDM dan Seputar Balita

\begin{tabular}{|c|c|c|c|}
\hline No & Mengetahui & $\begin{array}{c}\text { Belum } \\
\text { Mengetahui }\end{array}$ & Total \\
\hline 1 & 29 & 11 & 40 \\
\hline 2 & $72.5 \%$ & $27.5 \%$ & $100.0 \%$ \\
\hline
\end{tabular}

Data tersebut menunjukan bahwa ibunda bayi sebagian besar sudah bisa membedakan mitos-mitos yang berkembang dimasyarakat. Adapun ibunda bayi yang sudah mengetahui sebanyak 29 orang atau sebesar $72.5 \%$, sedangkan yang belum mengetahui adalah sebanyak 11 orang atau sebesar $27.5 \%$.

Setelah Pelaksanaan Kegiatan Pendampingan \& Penyuluhan

a. Manfaat Pelaksanaan Kegiatan

Setelah dilaksanakan kegiatan pendampingan dan penyuluhan, semua ibunda yang ikut serta dalam kegiatan diwawancarai satu persatu secara bergiliran sehingga bisa lebih tepat dan pasti mengetahui seberapa jauh informasi yang diserap dalam pendampingan dan penyuluhan yang diberikan.

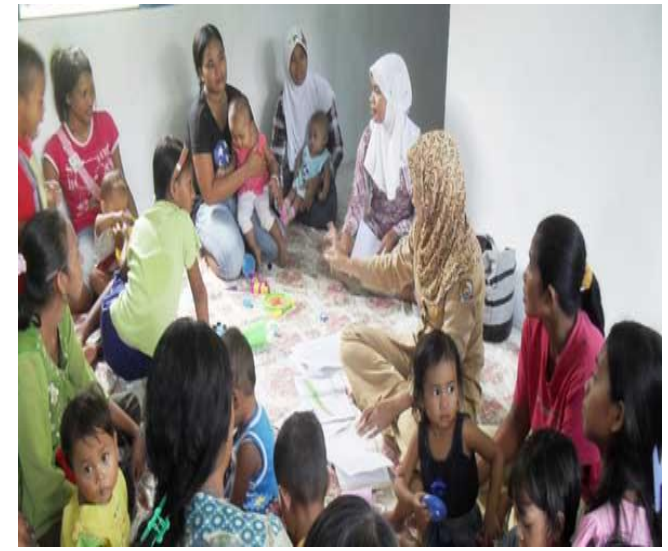

Gambar 1. Penyuluhan dan Turorial ASI dari Dokter Puskesmas.
Dari hasil wawancara yang dilakukan setelah penyuluhan, diperoleh data sebagai berikut

Tabel. 6 Distribusi Jawaban Wawancara tentang manfaat ASI, Imunisasi dan MitosMitos Inisiasi Menyusui Dini (IMD)

\begin{tabular}{c|c|c|c}
\hline No & $\begin{array}{c}\text { Sudah } \\
\text { Memahami }\end{array}$ & $\begin{array}{c}\text { Belum } \\
\text { Memahami }\end{array}$ & Total \\
\hline 1 & 36 & 4 & 40 \\
\hline 2 & $90.0 \%$ & $10.0 \%$ & $100.0 \%$ \\
\hline
\end{tabular}

Data tersebut menunjukan bahwa peserta kegiatan yang mendapatkan manfaat pelaksanaan pendampingan dan penyuluhan adalah 36 orang atau 90\%, sedangkan yang belum memahami akan manfaat dari pendampingan dan penyuluhan tersebut adalah 4 orang atau $0 \%$.

Hasil wawancara dan pendampingan menunjukkan bahwa ibunda yang tidak memberikan ASI pada anak, dikarenakan ibunda bayi kurang mendapatkan informasi tentang manfaat ASI, akan tetapi yang ibunda dapatkan adalah informasi seputar susu formula yang banyak ibu jumpai di televisi, radio, dan majalah sehingga ibu tergiur pada iklan tersebut dan memilih susu formula daripada ASI.

Dari hasil kuesioner yang dilakukan pada seluruh peserta didapatkan bahwa 29 responden (ibunda) yang tidak memberikan ASI pada anak, sehingga hampir semua $(72,5 \%)$ perkembangan anak menyimpang (kurang cepat menangkap ilmu atau pembelajaran) dan sering mengalami sakit dibandingkan dengan bayi yang mendapatkan ASI eksklusif.

Hal ini sesuai dengan Khamzah (2012) yang menyatakan bahwa pemberian ASI merupakan hal penting dalam tumbuh kembang anak karena di dalam ASI terdapat kandungan minyak omega-3 asam linoleat alfa yang sangat dibutuhkan bagi perkembangan anak dan tidak terdapat pada susu formula. Anak yang 
mendapatkan ASI sampai berusia 6 bulan akan lebih cepat berkembang dibandingkan dengan anak yang tidak diberikan ASI karena ASI mengandung unsur-unsur gizi yang dibutuhkan oleh anak agar anak dapat berkembang secara optimal.

Dengan adanya Pendampingan dan tutorial ASI ibunda bayi memiliki pemahaman untuk menyusui bayi secara ekslusif selama enam bulan, hal ini sesuai dengan Septiani, Budi dan Karbito (2017) yang menyimpulkan bahwa faktor yang paling dominan dalam pemberian ASI eksklusif adalah pengetahuan Ibu dalam memberikan ASI eksklusif memiliki peluang sebesar 13 kali lebih besar dibandingkan ibu yang memiliki pengetahuan kurang.

Pendampingan yang dilakukan dapat memberikan pengetahuan dan pemahaman kepada ibu-ibu tentang pentingnya pemberian ASI Eksklusif untuk meningkatkan imunitas dan kecerdasan. Hal ini sesuai dengan hasil kegiatan pengabdian wijayanti, dkk (2017) yang menyatakan bahwa pentingnya peningkatan pengetahuan dan pemahaman ASI bagi ibu menyusui karena ASI merupakan makanan terbaik yang memiliki kandungan gizi, enzim, hormon maupun kandungan zat imunologik dan anti infeksi.

Setelah dilakukan pendampingan terjadi peningkatan pemahaman ibu tentang pentingnya ASI Eksklusif dari hasil post test sebesar $90 \%$. Hal ini sesuai dengan hasil kegiatan penyuluhan yang dilakukan oleh Aditya, dkk. di Puskesmas Way Kandis Bandar Lampung (2015) yaitu Peningkatan pengetahuan tentang ASI akan meningkatkan pemahaman pentingnya pemberian ASI yang benar. Dengan pemahaman yang baik akan membentuk perilaku pemberian ASI yang baik, sehingga pada akhirnya akan meningkatkan derajat kesehatan ibu dan anak.
Pembentukan kader ASI eksklusif wilayah kerja Kelurahan Jepun dapat membantu melancarkan program pelatihan dan mendukung program pemberian ASI Ekslusif enam bulan pertama di Kelurahan Jepun, hal ini sesuai dengan pelatihan kader ASI yang dilakukan oleh Wijayanti, dkk. (2017) di Kabupaten Blora yang terbukti bisa meningkatkan angka cakupan pemberian ASI Ekslusif selama enam bulan pertama kelahiran setelah adanya pemberian edukasi kepada para kader ASI.

Dengan adanya kader ASI di wilayah Jepun ternyata memberi manfaat yaitu meningkatkan wawasan masyarakat tentang masalah menyusui bayi, hal ini sesuai dengan hasil kegiatan pengabdian Widayanti dan Wahyuningsih (2016) yaitu pemberdayaan kelompok pendukung ASI dapat meningkatkan keterampilan dan mengatasi masalah menyusui bayi.

Pemberian ASI berperan penting terhadap perkembangan anak sesuai dengan tahapan usianya, jika pemberian ASI pada anak kurang maka perkembangan anak cenderung akan menyimpang. Dari peserta yang mengikuti kegiatan ini sebagian besar belum pernah mendapatkan penyuluhan kesehatan dan simulasi mengenai ASI eksklusif untuk meningkatkan derajat kesehatan ibu dan anak. Sebelum dilakukan penyuluhan dan simulasi sebagian besar peserta tidak mengetahui sama sekali ASI eksklusif.

Setelah dilakukan peyuluhan dan simulasi peserta sudah mengetahui tentang cara memberikan ASI eksklusif dan menyimpan ASI yang baik serta benar dengan menjawab pertanyaa post-test seluruhnya dengan hasil rata-rata di atas $90 \%$.

Luaran lain dari penyuluhan dan pendampingan ASI eksklusif akhirnya terbentuk kader ASI (KASI) dengan menggandeng dokter dan bidan dari Puskesmas Kecamatan Tulungagung, Terciptanya modul pentingnya ASI eksklusif sebagai pembentuk sistem 
imunitas dan kecerdasan bagi bayi sebagai pegangan ibunda bayi.

\section{SIMPULAN}

Pelaksanaan pendampingan dan penyuluhan tutorial ASI ekslusif memberikan peningkatan pemahaman pengetahuan dan informasi yang wajib diketahui bagi setiap ibunda yang memiliki bayi. Dapat meningkatkan kualitas ibunda bayi dalam pemberian ASI Ekslusif serta dalam merawat bayi sejak dini. Dengan pemahaman yang baik akan memberikan perilaku pemberian ASI yang baik sehingga bisa memberikan sistem imunitas yang baik dan kecerdasan bagi bayi. Sebagai bahan literatur dan pengembangan ilmu pengetahuan khususnya dalam bahasan Pemberian ASI Ekslusif bagi Ibunda bayi.

Pemahaman ibunda bayi mengalami peningkatan Setelah dilakukan penyuluhan dan simulasi akan ASI eksklusif dan hendaknya setiap peserta mampu mengaplikasikan dan meyebarkan pengetahuan yang didapat dalam kegiatan ini agar dapat membantu meningkatkan derajat kesehatan ibu dan anak. Perlu dilakukan kegiatan serupa di pusat kesehatan masyarakat atau daerah lain yang belum memiliki kesempatan melaksanakan kegiatan ini supaya pengetahuan mengenai ASI eksklusif dapat lebih luas.

Terciptanya Kader ASI (KASI) sebagai wadah untuk melakukan promosi ASI eksklusif kepada seluruh masyarakat yang belum memahami dan mengetahui akan pentingnya ASI eksklusif serta mendukung dan membantu ibunda yang mempunyai masalah menyusui.

\section{DAFTAR PUSTAKA}

Dinas Kesehatan. (2016). Pedoman Umum Pemberian MP-ASI Lokal 2016 Dinas Kesehatan Provinsi Jawa Timur, Profil Kesehatan Provinsi Jawa Timur.

Hanafi, Y., (2012). Peningkatan
Kecerdasan Anak Melalui Pemberian ASI dalam AlQuran, ,Mutawâtir: Jurnal Keilmuan Tafsir Hadis. 2 (1), 27-45.

Heather \& Welford, (2001). Menyusui Bayi Anda. Jakarta: PT Dian Rakyat.

Khamzah, S.N. (2012). Segudang keajaiban ASI, Yogyakarta: Flash Book

Marimbi, H., (2010). Tumbuh Kembang, Status gizi, dan Imunisasi Dasar Pada balita, Yogyakarta: Nuha medika.

Mustofa dan Prabandari. (2010). Pemberian ASI Eksklusif dan Problematika Ibu Menyususi, YINYANG (Jurnal Studi Gender dan Anak). 5(2), 215-226

Roesli, U., (2008). Inisiasi Menyusui Dini plus ASI EKSLUSIF. Jakarta: Pustaka Bunda.

Septiani, Budi dan Karbito. (2017) FaktorFaktor yang Berhubungan dengan Pemberian ASI Eksklusif Oleh Ibu Menyusui yang Bekerja Sebagai Tenaga Kesehatan .Aisyah: Jurnal Ilmu Kesehatan 2 (2), 159 - 174

Werdika, Mardji dan Devi. (2014). Pengaruh Penyuluhan Asi Eksklusif Terhadap Pengetahuan Ibu Tentang Asi Eksklusif dan Sikap Ibu Menyusui di Kecamatan Kanigoro Kabupaten Blitar, Kejuruan, Jurnal Teknologi Kejuruan Dan Pengajaran. 37(1), 65-72.

Aditya.Utama, Puspitasari dan Nareswari (2016). Peningkatan Pengetahuan Ibu Usia Reproduktif melalui Penyuluhan dan Simulasi tentang ASI Eksklusif untuk Meningkatkan Derajat Kesehatan Ibu dan Anak di Puskesmas Way Kandis Bandar Lampung, Jurnal Pengabdian Masyarakat Ruwa Jurai. 1(1). 1-4.

Wijayati, Wardani, Muyassaroh dan Qomariyah (2017). Peningkatan Cakupan ASI di Wilayah Kelurahan Karangjati Kecamatan Blora Kabupaten Blora Melalui Pelatihan 
Kader ASI. Jurnal LINK, 13 (2), 24-

27

Widayanti.RS dan Wahyuningsih. IR (2016). Pemberdayaan Kelompok Pendukung ASI Eksklusif Dalam Gerakan Gemar ASI Eksklusif. Jurnal WARTA, 19 (1), 90-9 